\title{
Material Flow Analysis and Recycling of Newspaper in Allama Iqbal Town Lahore, Pakistan
}

\author{
Sadia Javed \\ College of Earth and Environmental Sciences, University of the Punjab, Pakistan
}

\begin{abstract}
The study deals with the extent of the recycling of Newspaper in Allama Iqbal Town (AIT) with a population of 117250. AIT was divided in the three categories as per its socioeconomic structure. Category A, high income group, category B, middle income group, category C, Low income group with the total of 13658 number of houses in all three groups. Two pathways involved in newspaper recycling were identified, one is the newspaper supply to the readers of AIT and the second one is the used newspaper cycle from the readers of AIT to the recycling units. Data on newspaper recycling was gathered from newspaper agencies, hawkers, and newspaper supply agents, residents of low, middle- and high-income groups, scavengers, junkshops and recycling unit. Sampling was carried in summer and winter to get the comparative data. Total of 560 samples were collected, thirty five from each category and total of 80 houses. Average newspaper supply to AIT was 1644tons/year where as average newspaper read in AIT was 1083.6 ton /year. Average Newspapers reused in AIT was 21.6 tons/year where as average newspaper recycled in AIT was 105.1tons/year. Total earning of the buyback centers and house person was $35028 \mathrm{Rs} /$ day for $451.5 \mathrm{Kg} /$ day and $3833 \mathrm{Rs} /$ day for $3010 \mathrm{Kg} /$ day. Based on these finding, an effective environmental and economical program of newspaper recycling has been recommended as a Single Stream and Efficient Newspaper Recycling Program in which both formal and informal sectors are mutually benefited and justified.
\end{abstract}

Keywords: Generation, Collection, Analysis, Reuse, Recycle.

\section{INTRODUCTION}

Recycling is very necessary to achieve reduction in the waste stream by promoting an economic environment, which favors the utilization of recycled metals. Recycling promotes separation and recovery of resources early as possible in waste generating processes in both the commercial and industrial sectors (Franklin and MacDonald, 1982).

Recycling is happening almost everywhere. It is roaring through the hall of government and business like a freight train and there is no stopping it. Cities and states across the country have same kind of recycling requirement. Home owners and businesses alike are now incorporating recycling in to their day to day activities at an increasing rate. Recycling is destined to become permanent part to manage waste in the country, but it will take some patience on our part to get there (Lund, 2001).

Solid waste generated in Lahore is $5186 \mathrm{Ton} /$ day. The generation rate is $0.65 \mathrm{Kg} / \mathrm{capita} /$ day (Solid Waste Department, 2008). Solid waste generation rate of Lahore is $0.85 \mathrm{~kg} / \mathrm{capita} /$ day (Adila, 2007).

Recycling is rapidly emerging as preferred strategy in the developed world and the same trend is being considered and adopted by the developing nations in order to deal with the problem of uncontrolled waste generation and disposal (Cheng et al. 2002; Qureshi, 2000; Ludwig et al. 2005).

Recycling uses much less energy compared to other methods of waste treatment and disposal and saved natural resources (Vencatasawmy et al. 2000; Van Beukering and Bouman, 2001; Gaines and Stodolsky, 1993; Stodolsky and Mintz, 1993).

It has been demonstrated that a well structured and executed recycling program can help to reduce the waste, its disposal and treatment cost (Kelley, 1992; Reams and Geaghan, 1969; Agunwamba et al. 1998; Bhattarai, 2000; Koli and Mahamuni, 2005; Singhal and Pandey, 2001).

In Pakistan however no proper legislation has been exacted, however sect oral guidelines for waste management in national environmental policy encourages the devising and implementation of plans for treatment of municipal wastes arising from rural and urban communities. It also aims to encourage promotion of reduction, reuse and recycling of municipal wastes (Pak, EPA, 2005).

Increasing population and improper waste disposal management system has created adverse environmental pollutions problems of water, air and land. People living near dumpsites suffer from smoke, smell and diseases. Uncollected waste attracts the rodents, fleas and flies which act as carriers of diseases (Younis, 1980; Hussain, 2005).

Waste generated from industries is sometimes toxic or hazardous. Bulk of toxic and hazardous wastes containing Arsenic, Cyanide, mercury and chlorinated hydrocarbon are generated in the industries (Franklin and Macdonald, 1982). 
Waste management has become a global issue. It is significant not only from environmental point of view but also from the prospective of business and economy (Bagchi, 1990). In different categories of wastes there are many opportunities for both prevention and resource recovery. Furthermore waste energy options exist among those solid waste streams that have high organic contents (Nicholas, 2003).

Laws are now books, programmers are being put in place, industry is making major investments in plants and equipment to process and reuse the materials collected for recycling. Markets are being developed and are slowly being changed. This is all for the good but it will take some time and expenditure of precious resources. But the basic is coming together and if we give it time recycling will assume a permanent and major role in our lives. The recycling landscape has evolved. So rapidly in the past few years that keeping up with the changes are major challenges (Ahsan, 1999).

Recycling remains however one of those elusive concept about which everyone thinks they have clear understanding until they begins to practice it. Although most people understand the relatively simple tasks required by individuals in order for them to participate, necessary for the interplay of both the public and private sectors needed return those materials industries as raw materials and the methods employed to do so require definitions other than common language as a matter of law (Sadgrove, 2000).

Recycling in many developed and under developed countries is generating substantial economic growth for the communities (Agarwal et al. 2005). According to findings of US EPA (2005) recycling and remanufacturing industries in the USA generate approximately one million manufacturing jobs and US\$100billion revenue. In Wilkes Barre, Pennsylvania, it resulted in a saving of US\$500,000 in land filling avoidance costs during the period between 1988 and 1991(Agunwamba et al. 1998). In England household waste recycling centers handle $16 \%$ of household waste (Woodward et al. 2004).

In Pakistan there is no proper solid waste management system from collection up to its final disposal. Solid waste generated in Pakistan is estimated to be 54,888 tons/day. The average generation rate of all types of Municipal solid Waste varies from $0.28 \mathrm{~kg} / \mathrm{capita} / \mathrm{day}$ (Khalid, 1993).

A large number of consumer products used in homes and work places ultimately become household hazardous waste various types of cell batteries are liaable to contain mercury, nickle, zinc and cadmium. These ultimately called groundwater contamination as they become part of leachat when land filled. These when incinerated contaminates air and generate toxic ash (Feher, 2007).

Solid waste comprise all the wastes arising from human and animal activities that normally solid and discarded as useless or unwanted (Tchbanoglous, 1993). Among the different types of solid wastes, residential or household waste represent about $30 \%$ of the overall municipal solid waste stream and the urban residential generate two times as much solid waste as their fellow rural citizen in Asia (World Bank, 1999).

\section{Statement of Problem}

There is no early study has been done so far on the newspaper recycling and how it works, so the whole life of newspaper recycling is necessitated to be done to examine the current status of newspaper recycling, its amount with respect to the newspaper readers and reusing and recycling activities to give forth the best newspaper recycling method to make it beneficial to environment and manpower involved in every single step.

\section{STUDY OBJECTIVE}

- To study the existing hierarchy of recycling of newspaper, practices and procedures.

- To estimate the percentage of newspaper recycling with respect to the scavengers, buy back centers and recycling units' activities.

- To create the best applicable, environmental and economical layout of whole recycling newspaper.

\section{STUDY AREA}

Allama Iqbal Town is the pure urban area, densely populated and spread over 1600 acres. It is named after Allama Iqbal, the National Poet of Pakistan. Development was started in the late 1970s and early 1980s. Its extent is marked by Multan Road to the west and north, and by Wahdet Road to the south. Neighboring localities are Wahdet Colony, Ichhra, Samanabad, Garden Town, Mustafa Town, Sabzazaar and Said Pur. Major markets (broad ways) are Karim Market (adjacent to Umer Block and Karim Block) - famous for the garments shops located there) and Moon Market (Dubai Chowk).The oldest open University in Pakistan Allama Iqbal Open University's Lahore campus is located in Raza Block of Allama Iqbal Town. Allama Iqbal Town (A.I. Town) consists of small residential areas called blocks. Famous blocks are Huma, Muslim, Ravi, Nizam, Neelam, Kamran, Nishtar, Jahanzeb, Kareem, Raza, Umar, College, Pak, Gulshan, Asif, Badar and many others.It come under UC 104 and 108 with an approximate population of 59663 in Union Council 104 and 57574 in Union Council 108, so the total population is 117237. There are 13649 numbers of houses in both 104 and 108 Union Councils. Average number of people living in each house hold is approximately 7-8 people per hose. AIT shows variety of blocks and consists of 27 blocks with mixed community with respect of middle 
income, low income and high income blocks Allama Iqbal Town is a commercial and residential locality in the south-western Lahore.

\section{METHODOLOGY}

Data collection was based on the objectives of the study. As the newspaper origin and recycling bring forth two different pathways, therefore study methodology comprised of data collection (Primary and secondary), questionnaire survey, collection and sampling of the waste. Primary and Secondary data were collected during the year 2009. The data on the physical composition of MSW of the study area were generated. The data include the details of sanitary staff, number of vehicles, and storage capacity of communal bins, numbers of bins, 3 bin system, recycling activities and behaviors, frequency of the vehicles visits to carry waste, collection and disposal method of MSW of Allama Iqbal Town. Detailed questionnaires was developed and distributed to get all the solid waste and recycling related knowledge and behavior of the people of the town. Allama Iqbal Town was divided into three economic classes (low, middle and high) based on area of house, property value and income of households. The questionnaire included name of the owner, house address, number of maids, number of family members, family system joint or nuclear, number of earners in a house, total monthly expenditures and type of food material used and as to what is the extent of reuse ad recycling and how it is done at house hold level. Stratified Random Sampling technique was adopted to collect the samples. Sampling was carried out during the month of April, May (summer), 2009 and January (winter), 2010.Total Number of the houses in each block was noted form map. Blocks were categorized according to their socioeconomic status as high income, middle income, and low income. Sample collection was continued for seven days and was started from Monday to Sunday to analyze the increasing and decreasing amount of waste. From each house seven samples were taken. Form Category A ten houses were selected, from Category B forty houses were selected and from Category C, thirty houses were selected. From each category thirty five samples were taken and from three categories total 560 samples were collected. Samples were collected in $4-5 \mathrm{Kg}$ plastic bags. It was also calculated and measured that how much percentage and amount of newspaper found in waste stream.

\section{RESULTS AND DISCUSSIONS}

According to the Table 1 three categorized group of Blocks under category A, B and C on the basis of Income level having different numbers of houses. Table shows that the high income group A has the least numbers of houses 2025. The middle income group B has 9207 numbers of houses that are more than A and low income group of houses C 2576. Total no of houses are 13658

\subsection{Total Population VS. Numbers of houses In each Category}

TABLE 1: Total population and number of houses in three categories of Blocks

\begin{tabular}{|l|l|l|}
\hline Name of category & Number of houses & Population \\
\hline A(high income) & 2025 & 17200 \\
\hline B (middle income) & 9057 & 78250 \\
\hline C (low income) & 2576 & 21800 \\
\hline TOTAL & $\mathbf{1 3 6 5 8}$ & $\mathbf{1 1 7 2 5 0}$ \\
\hline
\end{tabular}

According to this Table 1 total numbers of houses are 13658 houses and total population is 117250 of which 17200 in the Category A, 78250 in the category B, and 21800 in the category C of Allama Iqbal Town. The Middle income Group has the highest population with according to the highest numbers of houses among the three categories.

TABLE 2: Education Level at AIT

\begin{tabular}{|c|c|c|c|}
\hline Types of system & $\begin{array}{c}\text { High Income } \\
\text { group(Category A) }\end{array}$ & $\begin{array}{c}\text { Middle income } \\
\text { group (Category B) }\end{array}$ & $\begin{array}{c}\text { Low income group } \\
\text { (Category C) }\end{array}$ \\
\hline Matric & $\mathbf{6 \%}$ & $\mathbf{5 \%}$ & $\mathbf{3 0 \%}$ \\
\hline F.A. & $\mathbf{4 \%}$ & $\mathbf{5 \%}$ & $\mathbf{1 5 \%}$ \\
\hline B.A. & $\mathbf{4 0 \%}$ & $\mathbf{5 5 \%}$ & $\mathbf{2 8 \%}$ \\
\hline M.A. & $\mathbf{5 0 \%}$ & $\mathbf{3 5 \%}$ & $\mathbf{2 7 \%}$ \\
\hline
\end{tabular}

According to collected data major population of $\mathrm{A}$ and $\mathrm{C}$ lives in nuclear family system while majority of middle class lives in joint family system. The categories A \& B have majority of males and female $r$ in lees in number while category $\mathrm{C}$ has greater population of females. High income group have majority of masters and bachelors degree holder middle income group have majority of B.A degree while low income group have very less graduates. 
TABLE 3: Rates and Average Weight (Wt) of Each Day Newspaper (2009)

\begin{tabular}{|c|c|c|c|c|c|c|c|c|c|}
\hline \multirow[t]{2}{*}{$\begin{array}{l}\text { Sr. } \\
\text { No }\end{array}$} & \multirow[t]{2}{*}{ Newspaper } & \multicolumn{7}{|c|}{$\begin{array}{l}\text { Rates of the Newspaper (NP) in different days of a week in Rupees (Rs)/ } \\
\qquad \text { \& Weight (wt) in Kg }\end{array}$} & \multirow{2}{*}{$\begin{array}{c}\text { Average } \\
\text { Wt of the } \\
\mathrm{NP} / \text { week in } \\
\mathrm{Kg}\end{array}$} \\
\hline & & $\begin{array}{c}\text { Sun } \\
\mathrm{Rs} / \mathrm{Wt} \text { in } \\
\mathrm{Kg}\end{array}$ & $\begin{array}{c}\text { Mon } \\
\mathrm{Rs} / \mathrm{Wt} \text { in } \\
\mathrm{Kg}\end{array}$ & $\begin{array}{c}\text { Tues } \\
\mathrm{Rs} / \mathrm{Wt} \text { in } \\
\mathrm{Kg}\end{array}$ & $\begin{array}{c}\text { Wed } \\
\mathrm{Rs} / \mathrm{Wt} \text { in } \\
\mathrm{Kg}\end{array}$ & $\begin{array}{c}\text { Thurs } \\
\mathrm{Rs} / \mathrm{Wt} \text { in } \\
\mathrm{Kg}\end{array}$ & $\begin{array}{c}\text { Fri } \\
\mathrm{Rs} / \mathrm{Wt} \text { in } \\
\mathrm{Kg}\end{array}$ & $\begin{array}{c}\text { Sat } \\
\mathrm{Rs} / \mathrm{Wt} \text { in } \\
\mathrm{Kg}\end{array}$ & \\
\hline 1 & Jang & $12 / 0.4$ & $09 / 0.14$ & $09 / 0.14$ & $09 / 0.14$ & $09 / 0.14$ & $09 / 0.14$ & $09 / 0.14$ & 0.17 \\
\hline 2 & $\begin{array}{l}\text { Nawa-e - } \\
\text { Waqat }\end{array}$ & $12 / 0.30$ & $09 / 0.12$ & $09 / 0.12$ & $09 / 0.12$ & $09 / 0.12$ & $09 / 0.12$ & $09 / 0.12$ & 0.11 \\
\hline 3 & Din & $07 / 0.35$ & $07 / 0.12$ & $07 / 0.12$ & $07 / 0.12$ & $07 / 0.12$ & $07 / 0.12$ & $07 / 0.12$ & 0.15 \\
\hline 4 & Jinnah & $12 / 0.35$ & $09 / 0.12$ & $09 / 0.12$ & $09 / 0.12$ & $09 / 0.12$ & $09 / 0.12$ & $09 / 0.12$ & 0.15 \\
\hline 5 & Pakistan & $07 / 0.35$ & $07 / 0.12$ & $07 / 0.12$ & $07 / 0.12$ & $07 / 0.12$ & $07 / 0.12$ & $07 / 0.12$ & 0.15 \\
\hline 6 & Khabarein & $12 / 0.4$ & $09 / 0.13$ & $09 / 0.13$ & $09 / 0.13$ & $09 / 0.13$ & $09 / 0.13$ & $09 / 0.13$ & 0.16 \\
\hline 7 & Ausaf & $07 / 0.15$ & $07 / 0.12$ & $07 / 0.12$ & $07 / 0.12$ & $07 / 0.12$ & $07 / 0.12$ & $07 / 0.12$ & 0.12 \\
\hline 8 & Asas & $05 / 0.15$ & $05 / 0.12$ & $05 / 0.12$ & $05 / 0.12$ & $05 / 0.12$ & $05 / 0.12$ & $05 / 0.12$ & 0.12 \\
\hline 9 & Awaz & $12 / 0.15$ & $09 / 0.12$ & $09 / 0.12$ & $09 / 0.12$ & $09 / 0.12$ & $09 / 0.12$ & $09 / 0.12$ & 0.12 \\
\hline 10 & Waqat & $12 / 0.30$ & $09 / 0.12$ & $09 / 0.12$ & $09 / 0.12$ & $09 / 0.12$ & $09 / 0.12$ & $09 / 0.12$ & 0.11 \\
\hline 11 & Ajkal & $12 / 0.30$ & $09 / 0.12$ & $09 / 0.12$ & $09 / 0.12$ & $09 / 0.12$ & $09 / 0.12$ & $09 / 012$ & 0.11 \\
\hline 12 & Dawn & $22 / 0.40$ & $15 / 0.14$ & $15 / 0.14$ & $11 / 0.14$ & $15 / 0.14$ & $15 / 0.14$ & $15 / 0.14$ & 0.17 \\
\hline 13 & News & $22 / 0.40$ & $15 / 0.14$ & $15 / 0.14$ & $15 / 0.14$ & $15 / 0.14$ & $15 / 0.14$ & $18 / 0.14$ & 0.17 \\
\hline 14 & Nation & $22 / 0.40$ & 15.014 & $15 / 0.14$ & $15 / 0.14$ & $15 / 0.14$ & $15 / 0.14$ & $15 / 0.14$ & 0.17 \\
\hline 15 & Daily Times & $18 / 0.40$ & $15 / 0.14$ & $15 / 0.14$ & $15 / 0.14$ & $15 / 0.14$ & 150.14 & $15 / 0.14$ & 0.17 \\
\hline 16 & The Post & $12 / 0.30$ & $12 / 0.14$ & $12 / 0.13$ & $12 / 0.13$ & $12 / 0.14$ & $12 / 0.14$ & $12 / 0.14$ & 0.15 \\
\hline 17 & Record & $07 / 0.15$ & $07 / 0.14$ & $07 / 0.12$ & $12 / 0.12$ & $07 / 0.12$ & $07 / 0.12$ & $07 / 0.12$ & 0.12 \\
\hline 18 & Islam & $07 / 0.15$ & $07 / 0.14$ & $07 / 0.12$ & $07 / 0.12$ & $07 / 0.12$ & $07 / 0.12$ & $07 / 0.12$ & 0.12 \\
\hline 19 & Zarb-e-Momin & $07 / 0.12$ & $07 / 0.14$ & $07 / 0.12$ & $07 / 0.12$ & $07 / 0.12$ & $07 / 0.12$ & $07 / 0.12$ & 0.12 \\
\hline 20 & Akhbar-e-Jhan & $\begin{array}{l}35 / 0.3 / \mathrm{m} \\
\text { onth }\end{array}$ & - & - & - & - & - & - & 0.3 \\
\hline \multirow[t]{2}{*}{21} & Family & $\begin{array}{l}25 / 0.3 / \mathrm{m} \\
\text { onth }\end{array}$ & - & - & - & - & - & - & 0.3 \\
\hline & Total & & & & & & & & 2.66 \\
\hline
\end{tabular}

Table 3 reveals that newspaper rates are different on different days of the week. Newspapers rates are high on Sunday because of more number of pages. News papers are delivered on Sunday and with magazine. Similarly on Wednesday and Saturday some newspapers have high rates because they also provide magazines.

TABLE: 4 Percentages and weight of People Reading Newspaper at (AIT) in 2009

\begin{tabular}{|c|c|c|c|}
\hline Name of newspaper & $\begin{array}{c}\text { High Income } \\
\text { group(Category A) }\end{array}$ & $\begin{array}{l}\text { Middle income group } \\
\text { (Category B) }\end{array}$ & Low income group (Category C) \\
\hline $\begin{array}{l}\text { Percentage of people reading } \\
\text { newspaper }\end{array}$ & $60 \%$ & $30 \%$ & $10 \%$ \\
\hline $\begin{array}{c}\text { No of the newspaper in each } \\
\text { category }\end{array}$ & 1175 & 5878 & 1959 \\
\hline Weight in Kg & 1806 & 903 & 301 \\
\hline Dawn $(662.2 \mathrm{Kg})$ & $\begin{array}{c}8 \%(240.8 \mathrm{Kg}) \text { daily, } \\
5 \%(150.5 \mathrm{Kg}) \\
\text { weekend }\end{array}$ & $\begin{array}{c}2 \%(60.2 \mathrm{Kg}) \text { daily, } 5 \% \\
(150.5 \mathrm{Kg}) \text { weekend }\end{array}$ & $2 \%(60.2 \mathrm{Kg})$ weekend \\
\hline The News $(361.2 \mathrm{Kg})$ & $9 \%(270.9 \mathrm{Kg})$ daily & $2 \%(60.2 \mathrm{Kg})$ daily & $1 \%(30.1 \mathrm{Kg})$ weekend \\
\hline $\begin{array}{l}\text { The Nation } \\
(391.3 \mathrm{Kg})\end{array}$ & $10 \%(301 \mathrm{Kg})$ daily & $\begin{array}{c}2 \%(60.2 \mathrm{Kg}) \text { daily, } 4 \% \\
(120.4 \mathrm{Kg}) \text { weekend }\end{array}$ & $1 \%(30.1 \mathrm{Kg})$ weekend \\
\hline $\begin{array}{l}\text { Nawai Wakat } \\
(361.2 \mathrm{Kg})\end{array}$ & $5 \%(150.5 \mathrm{Kg})$ & $5 \%(150.5 \mathrm{Kg})$ daily & $2(60.2 \mathrm{Kg}) \%$ \\
\hline Jang $(903 \mathrm{Kg})$ & $\begin{array}{c}3 \%(90.3 \mathrm{Kg}) \text { daily } \\
16 \%(481.6 \mathrm{Kg}) \\
\text { weekend }\end{array}$ & $\begin{array}{c}1 \%(30.1 \mathrm{Kg}) \text { daily, } 7 \% \\
(210.7 \mathrm{Kg}) \text { weekend }\end{array}$ & $3 \%(90.3 \mathrm{Kg})$ \\
\hline Din & - & - & - \\
\hline Khabrain & - & - & - \\
\hline Any other $(210.7 \mathrm{Kg})$ & $4 \%(120.4 \mathrm{Kg})$ & $2 \%(60.2 \mathrm{Kg})$ & $1 \%(30.1 \mathrm{Kg})$ \\
\hline
\end{tabular}

Table 4 shows that category A read $60 \%$ of total newspaper which comprises 7224 newspapers in numbers and $1806 \mathrm{Kg}$ in weight per day. Category B read $30 \%$ of newspapers comprise of 3612 newspapers in weight and $903 \mathrm{Kg}$ in weight. Similarly category C read only $10 \%$ of newspapers, comprise of 1204 newspapers in numbers 
and $301 \mathrm{Kg}$ in weight. Total weight of the newspapers is obtained by multiplying numbers of newspapers with $0.25 \mathrm{Kg}$ (weight of each newspaper). Percentages and weight of each newspaper with respect to the daily and weekly .reading of the sub categories of newspapers is also described.

TABLE 5: Average Newspaper Supply to Allama Iqbal Town (AIT) in 2009

\begin{tabular}{|l|l|l|l|}
\hline Sr. No. & $\begin{array}{l}\text { Average newspaper Supply To } \\
\text { AIT } \\
\text { Kg/Day }\end{array}$ & $\begin{array}{l}\text { Average newspaper Supply } \\
\text { To AIT } \\
\text { Kg/month }\end{array}$ & $\begin{array}{l}\text { Average newspaper Supply To } \\
\text { AIT } \\
\text { Kg/Year }\end{array}$ \\
\hline 1. & 4209 & 126270 & 1536285 \\
\hline & Tons/day & Tons/month & Tons/year \\
\hline & 4.2 & 126.2 & 1536.2 \\
\hline
\end{tabular}

TABLE 6: Newspapers Circulation Rates of Lahore, 2009

\begin{tabular}{|l|l|l|l|l|}
\hline $\begin{array}{l}\text { Sr. } \\
\text { No. }\end{array}$ & Name of the newspaper & $\begin{array}{l}\text { Circulation Rate/per } \\
\text { day supply of } \\
\text { Newspaper }\end{array}$ & $\begin{array}{l}\text { Circulation Rate/per } \\
\text { month supply of } \\
\text { Newspaper }\end{array}$ & $\begin{array}{l}\text { Circulation Rate/per year } \\
\text { supply of Newspaper }\end{array}$ \\
\hline & Express & 43000 & 1290000 & 15480000 \\
\hline & Naw-e-waqat & 45000 & 1350000 & 16200000 \\
\hline & Jinnah & 15000 & 450000 & 5400000 \\
\hline & Jang & 48000 & 1440000 & 17280000 \\
\hline & Dawn & 13000 & 390000 & 4680000 \\
\hline & News & 10000 & 300000 & 3600000 \\
\hline & Nation & 8000 & 240000 & 2880000 \\
\hline & Waqat & 18000 & 540000 & 6480000 \\
\hline
\end{tabular}

Table 6 shows that the greatest circulation rate or supply of newspaper is that of Jang i.e. 48000 per day. Nawa-e waqat and Express are on the second and third number with circulation of 45000 and 43000 per day.

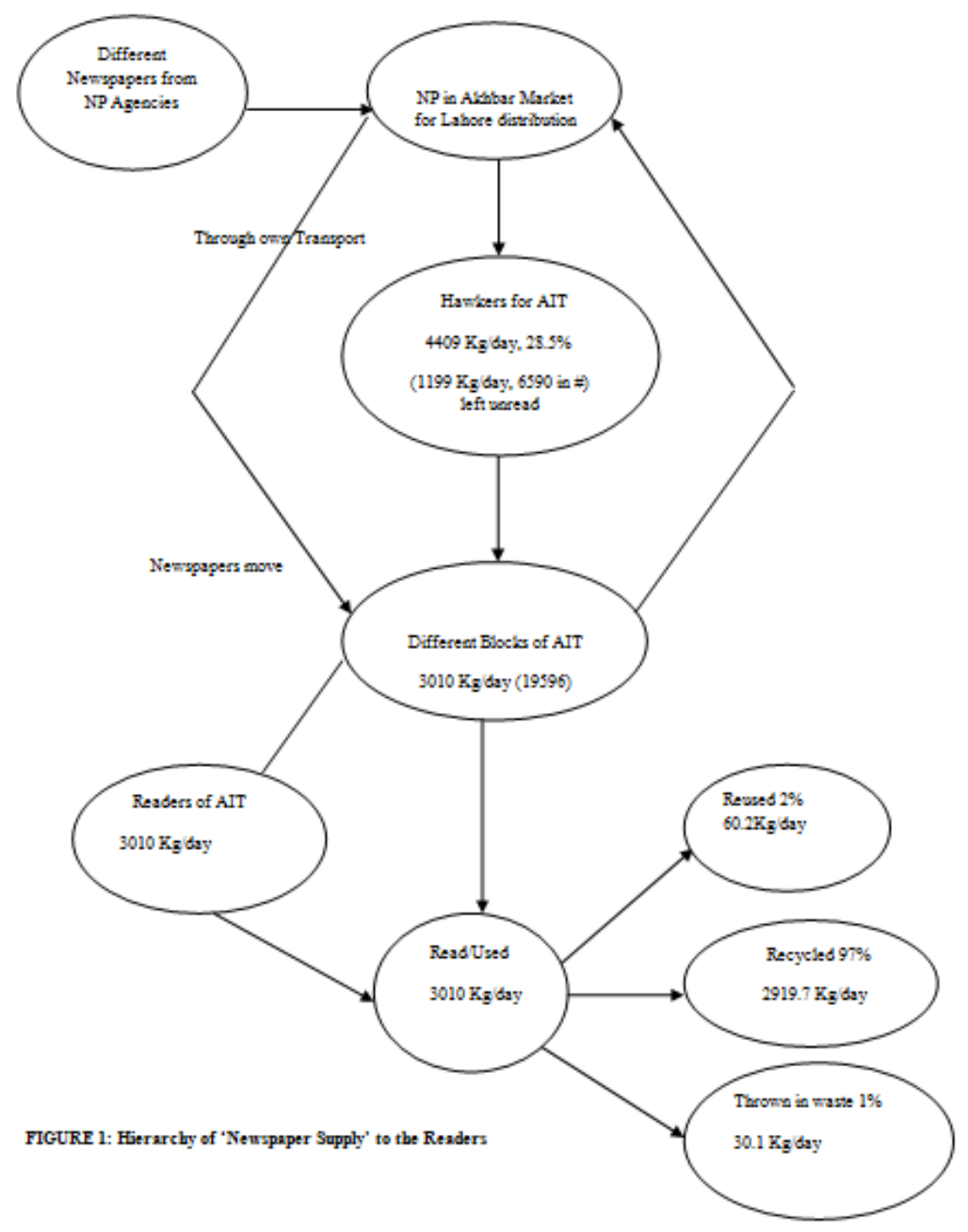




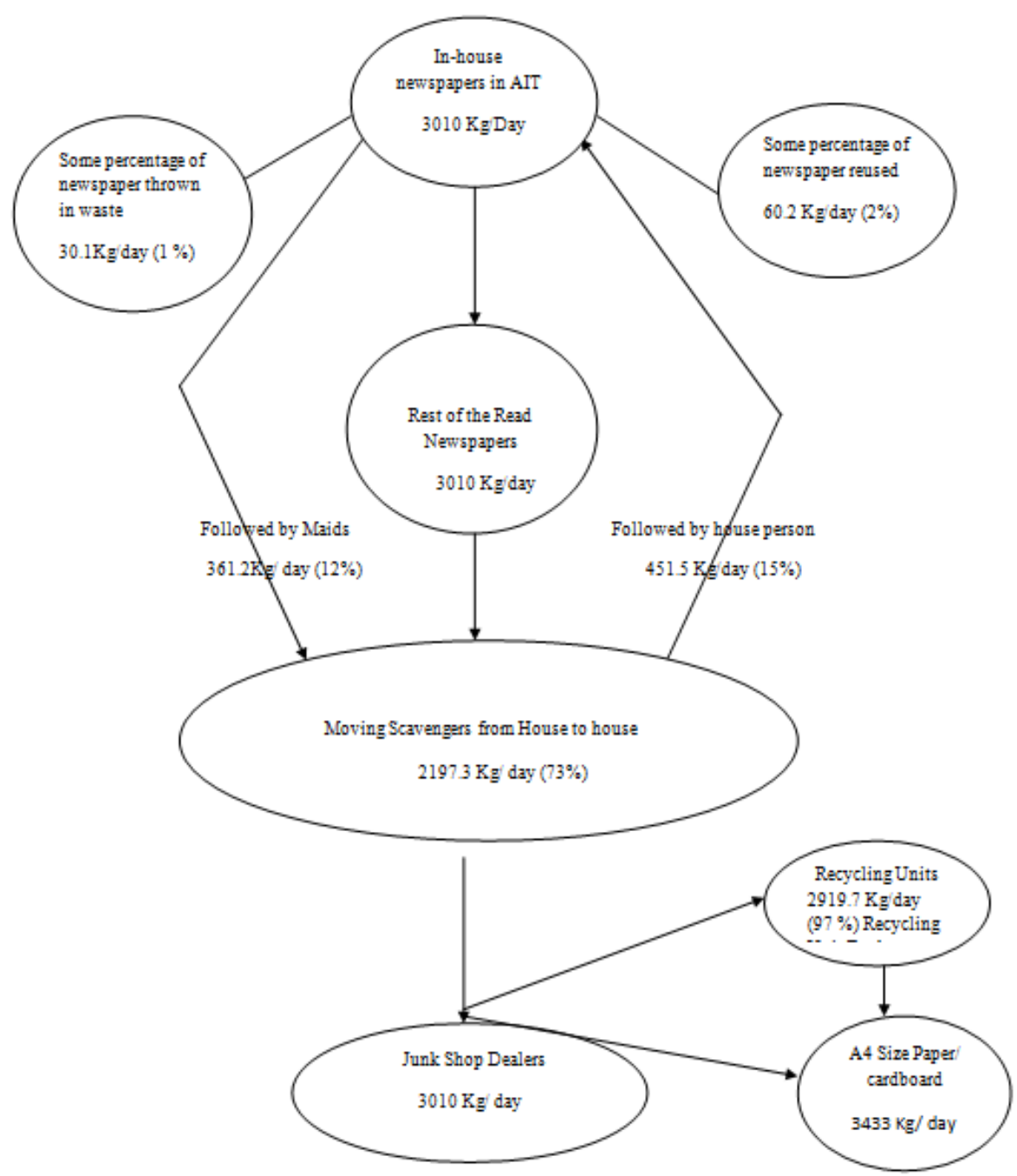

FIGURE 2: Hierarchy of 'Used News paper' to the Recycling Units

TABLE 7: Newspapers (NP) Weight \& Circulation Rates of Allama Iqbal Town, 2009

\begin{tabular}{|l|l|l|l|l|}
\hline Sr. No. & $\begin{array}{l}\text { Name of the } \\
\text { newspaper }\end{array}$ & $\begin{array}{l}\text { Circulation Rate 3 of Np/Wt/day } \\
\text { supply of Newspaper } \\
\text { (Newspaper *Average wt/ week) } \\
\text { wt in Kg }\end{array}$ & $\begin{array}{l}\text { Circulation Rate \# of } \\
\text { Np } / \mathbf{W t} / \mathbf{m o n t h} \\
\mathbf{W t} \text { in Kg }\end{array}$ & $\begin{array}{l}\text { Circulation Rate \# of } \\
\text { Np } / \mathbf{W t} / \text { Year } \\
\text { Wt in Kg }\end{array}$ \\
\hline 1 & Express & $3552 * 0.15=532.8$ & $76560 / 15984$ & $931480 / 194472$ \\
\hline 2 & $\begin{array}{l}\text { Naw-e- } \\
\text { waqat }\end{array}$ & $3280 * 0.11=360.8$ & $98400 / 10824$ & $1197200 / 131692$ \\
\hline 3 & Jinnah & $3565 * 0.15=534.7$ & $106950 / 16041$ & $1301223 / 195165.5$ \\
\hline 4 & Jang & $4010 * 0.17=681.7$ & $120300 / 20451$ & $1463650 / 248820.5$ \\
\hline 5 & Dawn & $3901 * 0.17=663.1$ & $17030 / 19893$ & $1423865 / 242031.5$ \\
\hline 6 & News & $3011 * 0.17=511.8$ & $90330 / 15354$ & $1099015 / 186807$ \\
\hline 7 & Nation & $3321 * 0.17=564.5$ & $99630 / 16935$ & $1212165 / 206042$ \\
\hline 8 & Waqat & $3273 * 0.11=360$ & $98190 / 10800$ & $1194645 / 129600$ \\
\hline Total \# of NP & & $\mathbf{2 3 1 2 5}$ & $\mathbf{6 9 3 7 5 0}$ & $\mathbf{8 4 4 0 6 2 5}$ \\
\hline $\begin{array}{l}\text { Total Weight } \\
\text { of the NP }\end{array}$ & & $\mathbf{4 2 0 9 . 4 K g}$ & $\mathbf{1 2 6 2 8 2} \mathbf{~ K g}$ & $\mathbf{1 5 3 6 4 3 1 ~ K g}$ \\
\hline
\end{tabular}

Table 7 shows that the greatest circulation rate or supply of newspaper was of Jang newspaper that was 4010 with weight of the newspaper was $681.7 \mathrm{Kg} /$ day followed by Dawn and Nation which were 3901 and 3321 with the weight of $663.1 \mathrm{Kg}$ and $564.5 \mathrm{Kg} /$ day respectively. Total Number of the newspaper supply per day in AlT was 23125 and total weight of the newspaper in $\mathrm{kg}$ was $4209.4 \mathrm{Kg} / \mathrm{day}$. Total weight was obtained by sum of average weekend weight of each type of newspaper, multiplying with the total number of each newspaper. 
TABLE 8: Average Newspaper Read/Used in Allama Iqbal Town in 2009

\begin{tabular}{|l|l|l|l|}
\hline Sr. No. & $\begin{array}{l}\text { Average newspaper read/used in } \\
\text { AIT } \\
\text { Kg/Day }\end{array}$ & $\begin{array}{l}\text { Average newspaper read/used } \\
\text { in AIT } \\
\text { Kg/month }\end{array}$ & $\begin{array}{l}\text { Average newspaper read/used in } \\
\text { AIT } \\
\text { Kg/Year }\end{array}$ \\
\hline 1. & 3010 & 90300 & 1083600 \\
\hline & Tons/day & Tons/month & Tons/year \\
\hline & 3.01 & 90.3 & 1083.6 \\
\hline
\end{tabular}

TABLE 9: Newspapers Reading Rates of Allama Iqbal Town, 2009

\begin{tabular}{|l|l|l|l|l|}
\hline Sr. No. & Name of the newspaper & $\begin{array}{l}\text { Circulation Rate of Np/Wt } \\
\text { /day supply of Newspaper } \\
\text { (Newspaper *Average wt/ } \\
\text { week) wt in Kg }\end{array}$ & $\begin{array}{l}\text { Circulation Rate \# of Np } \\
\text { /Wt/month } \\
\text { Wt in Kg }\end{array}$ & $\begin{array}{l}\text { Circulation Rate \# of Np } \\
\text { Wt/Year } \\
\text { Wt in Kg }\end{array}$ \\
\hline 1 & Express & $2442 * 0.15=366.3$ & $73260 / 10989$ & $879120 / 131868$ \\
\hline 2 & Naw-e-waqat & $2630 * 0.11=289.5$ & $78900 / 8685$ & $946800 / 10567.5$ \\
\hline 3 & Jinnah & $2815 * 0.15=422.2$ & $84450 / 12666$ & $1027415 / 154103$ \\
\hline 4 & Jang & $3726 * 0.17=633$ & $111780 / 18990$ & $1341360 / 231045$ \\
\hline 5 & Dawn & $2718 * 0.17=462$ & $81540 / 13860$ & $992070 / 168630$ \\
\hline 6 & News & $1572 * 0.17=267.2$ & $47160 / 8016$ & $573780 / 97528$ \\
\hline 7 & Nation & $2453 * 0.11=269.8$ & $52950 / 9000$ & $644225 / 109500$ \\
\hline 8 & Waqat & $\mathbf{1 9 5 9 6}$ & $73590 / 8094$ & $883080 / 98477$ \\
\hline $\begin{array}{l}\text { Total \# } \\
\text { of NP }\end{array}$ & & $\mathbf{3 0 1 0 ~ K g}$ & $\mathbf{5 8 7 8 8 0}$ & $\mathbf{8 8 3 0 8 0}$ \\
\hline $\begin{array}{l}\text { Total } \\
\begin{array}{l}\text { Weight } \\
\text { of } \\
\text { NP }\end{array}\end{array}$ & & & $\mathbf{9 0 3 0 0 ~ K g}$ & $\mathbf{1 0 9 8 6 5 0} \mathbf{K g}$ \\
\hline
\end{tabular}

Table 9 shows that the greatest reading rate was of Jang newspaper that was 3726 newspapers in numbers with the weight of $633 \mathrm{~kg} /$ day Dawn and Jinnah which were 2718 and 2815 with the weight of $462 \mathrm{Kg}$ and $422.2 \mathrm{Kg}$ /day respectively. Total Number of the newspaper supply per day in AIT was 19596 and total weight of the newspaper in $\mathrm{kg}$ was $3010 \mathrm{Kg} / \mathrm{day}$. Total weight was obtained by sum of average weekend weight of each type of newspaper, multiplying with the total number of each newspaper.

TABLE 10: Average Newspaper Read/Used in Allama Iqbal Town in 2009

\begin{tabular}{|l|l|l|l|}
\hline Sr. No. & $\begin{array}{l}\text { Average newspaper read/used in } \\
\text { AIT } \\
\text { Kg/Day }\end{array}$ & $\begin{array}{l}\text { Average newspaper read/used } \\
\text { in AIT } \\
\text { Kg/month }\end{array}$ & $\begin{array}{l}\text { Average newspaper read/used in } \\
\text { AIT } \\
\text { Kg/Year }\end{array}$ \\
\hline 1. & 3010 & 90300 & 1083600 \\
\hline & Tons/day & Tons/month & Tons/year \\
\hline & 3.01 & 90.3 & 1083.6 \\
\hline
\end{tabular}

TABLE 11: Average Newspaper Reused in Allama Iqbal Town in 2009

\begin{tabular}{|l|l|l|l|}
\hline Sr. No. & $\begin{array}{l}\text { Average newspaper reused in AIT } \\
\text { Kg/Day }\end{array}$ & $\begin{array}{l}\text { Average newspaper reused in } \\
\text { AIT } \\
\text { Kg/month }\end{array}$ & $\begin{array}{l}\text { Average newspaper reused in } \\
\text { AIT } \\
\text { Kg/Year }\end{array}$ \\
\hline 1. & 60.2 & 1806 & 216720 \\
\hline & Tons/day & Tons/month & Tons/year \\
\hline & 0.09 & 1.806 & 21.6 \\
\hline
\end{tabular}

TABLE 12: Total Earnings of Scavengers of Allama Iqbal Town in 2009

\begin{tabular}{|l|l|l|l|}
\hline Recyclable Items & $\begin{array}{l}\text { Total Quantity sold at Average price (B) Rs. / ton } \\
\text { junkshop dealers by } \\
\text { scavengers (A) tons/year }\end{array}$ & $\begin{array}{l}\text { Total earning of scavengers } \\
\text { through sale of recyclables } \\
\text { (C= AB) Rs. Million per } \\
\text { Year }\end{array}$ \\
\hline Glass & 6526.4 & 11500 & 75 \\
\hline Plastic & 81196.4 & 15000 & 1217 \\
\hline Newspaper & 20086.4 & 8500 & 170 \\
\hline Total & $\mathbf{1 0 7 8 0 9 . 2}$ & $\mathbf{3 5 0 0 0}$ & $\mathbf{1 4 6 2}$ Million \\
\hline
\end{tabular}

Table 12 illustrates that large quantity of the Glass was sold in 2009 that is 81196.4 tons /year and the profit gained from it is 1217 million/year that is greater than the paper, 170million/year for 20086.4tons/year and 
greater than glass that is 75 million /year for 6526.4 tons/year. So the plastic recycling business is more than the paper and glass

TABLE 13: Total Earning of Junk Shop Dealers in Allama Iqbal Town, 2009

\begin{tabular}{|l|l|l|l|}
\hline Recyclable Items & $\begin{array}{l}\text { Total Quantity available at } \\
\text { junkshop for sale to } \\
\text { recycling industry (A) } \\
\text { tons/year }\end{array}$ & $\begin{array}{l}\text { Average rate at which Total earning of junk shop } \\
\text { recyclables are sold to owners through sale of } \\
\text { Recycling industry (B) Rs. } \\
\text { Per ton } \\
\text { recyclables } \\
\text { (C=A B) Rs. Million per } \\
\text { Year }\end{array}$ \\
\hline Glass & 6526.4 & 14850 & 96 \\
\hline Plastic & 81196.4 & 16500 & 133 \\
\hline News paper & 20086.4 & 11000 & 220 \\
\hline Total & 107809.2 & & 449 \\
\hline
\end{tabular}

It is clear from the Table 13 that total average quantity of paper is 20086.4 tons/year present in the junkshops for sale and is higher than the quantity of glass and plastic .similarly total earning of the junkshop dealers are higher for the sale of paper as compared to the plastic and glass.

TABLE 14: Profit of Scavengers 2009

\begin{tabular}{|l|l|l|l|l|}
\hline Recyclable items & $\begin{array}{l}\text { Average purchase rate } \\
\text { of recyclable } \\
\text { Rs. Per Kg }\end{array}$ & $\begin{array}{l}\text { Average selling rate of } \\
\text { Recyclables } \\
\text { Rs. Per Kg }\end{array}$ & $\begin{array}{l}\text { Profit } \\
\text { Rs. Per Kg }\end{array}$ & Profit\% \\
\hline Glass & 11.5 & 14.85 & 3.35 & 22 \\
\hline Plastic & 15 & 16.5 & 1.5 & 9 \\
\hline NewsPaper & 8.5 & 11 & 2.5 & 29.4 \\
\hline
\end{tabular}

TABLE 15: Percentage Commission of the Agents and Sub agents

\begin{tabular}{|l|l|l|}
\hline $\begin{array}{l}\text { Commission of the Hawkers from the } \\
\text { Newspaper Agency } \%=A\end{array}$ & $\begin{array}{l}\text { Commission of the sub } \\
\text { agents from the Hawkers } \\
\%=B\end{array}$ & $\begin{array}{l}\text { Greater part of the commission } \\
\text { received A-B }=\end{array}$ \\
\hline 42 & 33 & $42-33=9$ (received by Hawker) \\
\hline
\end{tabular}

TABLE 16: Percentage of Waste Minimization at Source per day per house of AIT

\begin{tabular}{|l|l|l|l|l|l|l|}
\hline Sr. No. & Name of items & $\begin{array}{l}\text { Generation } \\
(\mathbf{K g}) \\
\mathbf{G}\end{array}$ & Rate & $\begin{array}{l}\text { Collection } \\
(\mathbf{K g}) \\
\mathbf{C}\end{array}$ & $\begin{array}{l}\text { Rate } \\
\text { minimization (kg) } \\
\text { G-C }\end{array}$ & $\begin{array}{l}\text { Pource } \\
\text { waste Minimization } \\
\text { at source }\end{array}$ \\
\hline 1 & Food waste & 1.41 & 1.28 & 0.13 & 9 \\
\hline 2 & Yard waste & 0.32 & 0.31 & 0.01 & 3 \\
\hline 3 & Cardboard & 0.35 & 0.26 & 0.09 & 26 \\
\hline 4 & Paper & 0.31 & 0.21 & 0.10 & 32 \\
\hline 5 & Newspaper & $\mathbf{0 . 2 0}$ & $\mathbf{0 . 1 5}$ & $\mathbf{0 . 0 5}$ & $\mathbf{2 5}$ \\
\hline 6 & Tetra packs & 0.41 & 0.32 & 0.09 & 22 \\
\hline 7 & Plastic & 0.38 & 0.29 & 0.09 & 24 \\
\hline 8 & PET & 0.49 & 0.37 & 0.12 & 25 \\
\hline 9 & Glass & 0.30 & 0.27 & 0.03 & 10 \\
\hline 10 & Metal & 0.27 & 0.23 & 0.04 & 15 \\
\hline 11 & Textiles & 0.14 & 0.11 & 0.03 & $\mathbf{0 . 7 8}$ \\
\hline Total & & $\mathbf{4 . 5 8}$ & $\mathbf{3 . 8 0}$ & $\mathbf{1 7 . 0}$ \\
\hline
\end{tabular}

TABLE 17: Generation and Collection Rates of Three Classes of Iqbal Town

\begin{tabular}{|l|l|l|l|l|}
\hline Class & $\begin{array}{l}\text { Per capita Generation } \\
\text { Rate (Kg) }\end{array}$ & $\begin{array}{l}\text { Per capita Collection } \\
\text { Rate(Kg) }\end{array}$ & $\begin{array}{l}\text { Per capita Source } \\
\text { Minimization (Kg) }\end{array}$ & $\begin{array}{l}\text { Percentage } \\
\text { Minimization at Source }\end{array}$ \\
\hline High income & 0.82 & 0.72 & 0.10 & 12.2 \\
\hline Middle income & 0.82 & 0.65 & 0.17 & 20.7 \\
\hline Low income & 0.76 & 0.60 & 0.16 & 22.1 \\
\hline Average & $\mathbf{0 . 8 0}$ & $\mathbf{0 . 6 6}$ & $\mathbf{0 . 1 4}$ & $\mathbf{1 7 . 5}$ \\
\hline
\end{tabular}

TABLE 18: Average Newspaper from AIT to Recycling Unit

\begin{tabular}{|l|l|l|l|}
\hline Sr.No & $\begin{array}{l}\text { Average newspaper Recycled } \\
\text { Kg/Day }\end{array}$ & $\begin{array}{l}\text { Average newspaper Recycled } \\
\text { Kg/month }\end{array}$ & $\begin{array}{l}\text { Average newspaper Recycled } \\
\text { Kg/Year }\end{array}$ \\
\hline 1. & 2919.7 & 87591 & 1051092 \\
\hline & Tons/day & Tons/month & Tons/year \\
\hline & 2.91 & 87.5 & 105.1 \\
\hline
\end{tabular}


TABLE 19: Average Earning and Economic Potential of Newspaper Recycling

\begin{tabular}{|l|l|l|l|l|}
\hline Sr. No & Category Involved & $\begin{array}{l}\text { Earning } \\
\text { Rs } / \text { day }\end{array}$ & Earning Rs/month & $\begin{array}{l}\text { Earning } \\
\text { Rs/ Year }\end{array}$ \\
\hline 1 & Scavengers & 18674 & $\mathbf{5 6 0 3 1 1}$ & $\mathbf{2 0 1 7 1 1 9 6 0}$ \\
\hline 2 & Home persons & $\mathbf{3 8 3 3}$ & $\mathbf{1 1 4 9 9 0}$ & $\mathbf{4 1 3 9 6 4 0 0}$ \\
\hline 3 & Buyback Centers & $\mathbf{3 5 0 2 8}$ & $\mathbf{1 0 5 0 8 4 0}$ & $\mathbf{3 7 8 3 0 2 4 0 0}$ \\
\hline
\end{tabular}

TABLE 20: Percentage of Newspapers Reuse and Recycling and in waste stream

\begin{tabular}{|c|c|c|c|c|c|c|c|c|c|}
\hline \multirow{3}{*}{$\begin{array}{l}\text { Redistribut } \\
\text { ion among } \\
\text { each } \\
\text { category }\end{array}$} & \multicolumn{3}{|c|}{ Newspapers Reused } & \multicolumn{3}{|c|}{ Newspapers Recycled } & \multicolumn{3}{|c|}{ Thrown in Waste Stream } \\
\hline & \multicolumn{3}{|c|}{ 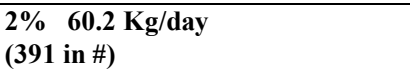 } & \multicolumn{3}{|c|}{$\begin{array}{l}97 \% \quad 2919.7 \mathrm{Kg} / \text { day } \\
(19008 \text { in \#) }\end{array}$} & \multicolumn{3}{|c|}{ 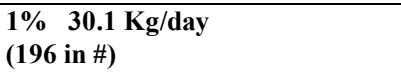 } \\
\hline & $\begin{array}{l}\text { High } \\
\text { Income } \\
\text { group A }\end{array}$ & $\begin{array}{l}\text { Middle } \\
\text { Income } \\
\text { Group B }\end{array}$ & $\begin{array}{l}\text { Low } \\
\text { Income } \\
\text { Group C }\end{array}$ & $\begin{array}{l}\text { High } \\
\text { Income } \\
\text { group A }\end{array}$ & $\begin{array}{l}\text { Middle } \\
\text { Income } \\
\text { Group B }\end{array}$ & $\begin{array}{l}\text { Low } \\
\text { Income } \\
\text { Group C }\end{array}$ & $\begin{array}{l}\text { High } \\
\text { Income } \\
\text { group A }\end{array}$ & $\begin{array}{l}\text { Middle } \\
\text { Income } \\
\text { Group B }\end{array}$ & $\begin{array}{l}\text { Low } \\
\text { Income } \\
\text { Group C }\end{array}$ \\
\hline $\begin{array}{l}\text { of } \mathrm{Np} / \\
\text { Day } \\
\end{array}$ & 195 & 97 & 97 & 4752 & 5702 & 9504 & 78 & 107 & 10 \\
\hline $\begin{array}{l}\text { Wt of } \mathrm{Np} \\
\text { in } \mathrm{Kg} / \mathrm{Day}\end{array}$ & 30.1 & 15 & 15 & 730 & 876 & 1460 & 12.0 & 16.5 & 1.5 \\
\hline
\end{tabular}

Table 20 shows that the maximum numbers of the newspaper were recycled or went for recycling each day. Recycling newspaper activity was $97 \%$, comprised of $2919.7 \mathrm{Kg} /$ day rather than newspaper reuse that were $2 \%$, comprised of $60.2 \mathrm{Kg} /$ day. Newspaper in the waste stream was found very low that was only $1 \%$, comprised of $30.1 \mathrm{Kg} /$ day. Further division of the percentage was also manifested in the table according to the $\mathrm{A}, \mathrm{B}$, and $\mathrm{C}$ category of the waste. Newspapers in numbers and in weight were also given

TABLE 21: Average Newspaper from AIT to Recycling Unit

\begin{tabular}{|l|l|l|l|}
\hline Sr. No. & $\begin{array}{l}\text { Average newspaper Recycled } \\
\text { Kg/Day }\end{array}$ & $\begin{array}{l}\text { Average newspaper Recycled } \\
\text { Kg/month }\end{array}$ & $\begin{array}{l}\text { Average newspaper Recycled } \\
\text { Kg/Year }\end{array}$ \\
\hline 1. & 2919.7 & 87591 & 1051092 \\
\hline & Tons/day & Tons/month & Tons/year \\
\hline & 2.91 & 87.5 & 105.1 \\
\hline
\end{tabular}

TABLE 22: Average Earning and Economic Potential of Newspaper Recycling

\begin{tabular}{|l|l|l|l|l|}
\hline Sr. No & Category Involved & $\begin{array}{l}\text { Earning } \\
\text { Rs } / \text { day }\end{array}$ & Earning Rs/month & $\begin{array}{l}\text { Earning } \\
\text { Rs/ Year }\end{array}$ \\
\hline 1 & Scavengers & $\mathbf{1 8 6 7 4}$ & $\mathbf{5 6 0 3 1 1}$ & $\mathbf{2 0 1 7 1 1 9 6 0}$ \\
\hline $\mathbf{2}$ & Home persons & $\mathbf{3 8 3 3}$ & $\mathbf{1 1 4 9 9 0}$ & $\mathbf{4 1 3 9 6 4 0 0}$ \\
\hline $\mathbf{3}$ & Buyback Centers & $\mathbf{3 5 0 2 8}$ & $\mathbf{1 0 5 0 8 4 0}$ & $\mathbf{3 7 8 3 0 2 4 0 0}$ \\
\hline
\end{tabular}

\subsection{Products of the Newspaper Recycling}

Packages has the capability of producing 100\% recycled paper. Various grades of paper and board (shipping, cartons, newsprint, magazines, and imported waste paper) are collected and then shredded. This is fed to a huge mixer where a controlled percentage of virgin pulp and used paper are mixed together to produce material for recycled paper Packages is producing high quality paper and Cardboard since 1965 using environment friendly manufacturing processes. This is the largest unit for the recycling of Newspaper into new products. Packages has transferred and relocated its paper manufacturing facilities from the existing location to a new site $54 \mathrm{~km}$ from the present one and is known as 'Bulleh Shah Paper Mill Packages limited' in Kasur. This will enable it to radically increase its paper and paperboard production from 100,000 to 300,000 tons per year.150 to 200 tons of Newspapers/ month from different areas of Lahore recycle in Packages Kasur.

\section{CONCLUSION AND RECOMMENDATION}

The Existing recycling patterns of newspaper in Allama Iqbal Town is almost similar to the other areas of Lahore. It has a complete series of procedures through which it is functional, but it is still unsatisfied and not through the proper channel. Actually the fact is this that there is no supervision of recycling patterns and behaviors.

According to the number of newspaper readers and the newspaper used, the number of newspaper recycling is not that efficient that could bring the real business and real sort of profit. There is still no policy and measurements in recycling process govern by government. 
There are no set of standards and quality on which basis the recycling of newspaper is going on. No environmental audits and environmental action is going on recycling of paper and newspaper and even nobody bothers about it. There are set actual and fixed rates over which used newspapers are sold to scavengers and mid dealers. There are different rates and people set their own rates in the recycling business.

There are many Buy back Centers in Allama Iqbal Town that used to collect the recyclables newspaper from the scavengers giving them some profit and then they sale it to Packages for recycling but there is no proper record of them and their profit neither they give anything to government.

People are also not very well informed and aware about recycling and positive effects of recycling in their surroundings and planet. Newspapers are also reused by the people but in a very small amount, most of the people used to throw them along with other waste.

There is no weighing bridge or any other source to make the record of the amount of the newspaper recycling/ generated per day. Not only the financial aspects of the systems are analyzed but, also the environmental, social and economical aspects of newspaper recycling

Large numbers of people are those who are perfectly ignorant of 3- bin- Systems and recycling. During the survey it was observed that there is no any proper market for recyclable materials, only shops and are present very far and randomly in one or two blocks so if the people collect the recyclable materials then they cannot sale them continently.

People are also very reluctant to behave for the better and clean environment by adopting simple habits. It was also observed that if the people will train and facilitate towards 3- bin System and 3 R's approach then it will not be less than a curse for them.

- Economically, recycling of newspaper is profitable and is providing benefits at each of its steps from making to use and from used form to recycled products. Recycling of newspaper is a great industry and business in the form of Newspaper recycling unit in Pakistan as Pakages.

- Socially, newspaper recycling is beneficial to the maids as the sale it and earn some income. Similarly recycling of newspaper creates jobs as scavengers, buyback centers and workers in the recycling units are doing their jobs because of this business of recycling newspaper.

- Environmentally, recycling of newspapers preserves the environment as by recycling paper, destruction of forests can be prevented. Today, a number of forests are being destroyed to meet the ever increasing demand of paper. Recycling a ton of newspaper is equivalent to saving 12 trees. Additional energy is consumed to extract and transport cut down trees. Transportation means using vehicles that run on fuels like diesel and gasoline. These fuels are considered the main source of green gas emissions. As recycling conserves energy, this results in less fuel being utilized. Thus, a lower amount of carbon dioxide will be released into the environment.

\subsection{Recommendations}

After concluding the existing recycling cycle and patterns of newspaper in Allama Iqbal Town, following is the suggested layout to address the proper, managed and efficient newspaper paper recycling process for AIT.

\subsubsection{Single Stream \& Efficient Newspaper Recycling Program}

\section{- Step $\longrightarrow$ 1: NP Agencies raise $2 \%$ NP prices/cost}

Description of Step 1

Price or the cost of the newspapers for supply to the readers if increases to $2 \%$ it will be further consumed on next steps of efficient NP recycling. One may think it's an environmental safety cost. (Note: $1 \%$ extra commission will be offer to the hawker by NP agency other than the routine commission)

- Step $\longrightarrow 2$ : NP Hawkers offer 2-3\% (depending upon the amount of the monthly bill) billing discount to the newspapers buyers of AIT.

\section{Description of Step 2}

This offer will be provided to the readers for returning back the read newspapers to the subagents of NPhawkers. Depending upon the amount of the bill means according to the monthly class of the bill if it is high at the end of the month the hawker will offer $3 \%$ discount on total amount of the bill to buyer and if it is less amount of bill than the offer of discount will be $2 \%$.

- Step $\longrightarrow$ 3: Collection of the read-NP from the houses by NP hawker's subagents

Description of Step 3

House person will save daily read newspapers throughout the month to return it back to the newspaper supply subagent. For this they will be facilitated by $2-3 \%$ discount on the total bill. All these read newspapers will be collected by NP- subagents at the end of the month. (Note: $1 \%$ extra commission will be offer to the NP supply subagent by NP- Hawker other than the routine commission)

- $\quad$ Step $\rightarrow$ 4:Used /old newspaper uptake by Newspaper Agency

\section{Description of Step 4}


Newspaper agency will be taking read/old newspapers from the hawkers of AIT on their own transport. This will reduce the cost and so many other pathways and routes of read newspaper reaching the recycling units.

- Step $\longrightarrow$ 5: Newspaper taken up by the Recycling Unit

Description of Step 5

Newspapers will be taking up by recycling unit from the NP agency on their own transport. Newspaper agency will be paid by recycling unit for the amount of read newspaper @ of per Kg of newspapers. Recycling unit will pay lesser amount to the NP agency than they pay to buyback centers for recycling newspaper. For example if recycling unit pay Rs. $15 / \mathrm{Kg}$ of newspapers to buyback centers than it will be paying Rs.11 or 12/Kg of newspapers to the NP agency. (Note: The save amount of Rs 2 or $3 / \mathrm{Kg}$ of the newspaper will be utilizing by the recycling unit over its transportation expanses for the collection of read/old newspapers)

- Step $\longrightarrow$ 6: Steps taken by the Government (Taxes)

\section{Description of Step 6}

Government would reduce the rate of taxes levy on the NP-recycling unit by $1-2 \%$ and would raise the taxes levy on the NP Agency by 1-2 \%.

- Step $\longrightarrow$ 7: Cheaper Newspaper recycling products by Recycling units

\section{Description of Step 7}

A4 size printer paper and cardboard (NP Recycled Products) will be available in the market at cheaper price than ever due to the tax reduction on the Newspaper recycling unit by 1-2 \%. (Note: The 1-2 \% Tax appraisal on the NP Agency will be levied by the government because of the income, Agency will be earning by involving in newspaper recycling)

\subsubsection{Benefits:}

- Single handed and well programmed NP Recycling

- Proper record keeping of exact amount of the NP recycled

- Government will be benefited

- Hawkers/and Subagents will be benefited

- Household person will be benefited

- Environment will be saved

\section{REFERENCES}

[1] Franklin, J. N and Macdonald, G. R (1982) Paper Manufacturing and Paper Making, McGraw Hill, Publishing Book Company, pp, 135-438.

[2] Lund, H.F. (2001) the McGraw Recycling Hand Book, 2nd Ed, McGraw Hill, New York.

[3] Solid Waste Management Department (2008) SWM Office Report, Lahore

[4] Batool, S. A. (2007) Environmental System Analysis of Municipal Solid Waste Management Application of the IWM-2 Model, PhD Thesis College of Earth \& Environmental Sciences, University of the Punjab, Lahore,

[5] Cheng, Y. (2002) the composition Trend and impact of Urban Solid Waste in Beijing, Journal of Environmental Sciences, Springer netherlands Vol,135, pp, 21-30.

[6] (Vencatasawmy et al. 2000; Van Beukering and Bouman, 2001; Gaines and Stodolsky, 1993; Stodolsky and Mintz, 1993). Vencatasawmy et al., 2000;

[7] Van Beukering and Bouman, 2001

[8] Kelley, 1992

[9] Koli, J.N and Mahamuni, G.R (2005) Paper manufacturing and Paper making, McGraw Hill publishing Book Company, pp, 135-438.

[10] (Pak, EPA, 2005). EPD, (2005), Recovery and Recycling of Municipal Solid Waste Reduction, Fact Sheet.

[11] Younis, M. (1980) Solid Waste management for the City of Lahore, "Mimeo Lahore, Pakistan; Lahore Municipal corporation”,pp.45-56.

[12] (Franklin and Macdonald, 1982).

[13] (Bagchi, 1990).

[14] Hussain, 2005

[15] Nicholas, P. Cheremisinoff. (2003) Hand Book of Solid Waste Management and Waste Minimization Technology Better Worth Heinenauer Bostan, London, pp, 1-2.

[16] Ahsan, N. (1999) Solid Waste Management Plan for Indian Mega Cities, Printer Publisher, New Dehli.

[17] Sadgrove, K. H. (2000) A to Z Corporate Environmental Management Earth Publication Ltd, London,

[18] Agarwal , A., Singhmar, A.., Kulshresther, M., and Mittal, A.K. (2005) Municipal Solid waste Recycling and associated Markets in Dehli, india, Resources, Conservation and Recycling, 44(1), pp. 73-90.

[19] Agunwamba, J.C. (1998) Analysis of Scavengers Activities and Recycling in Some Cities of Nigeria, Journal of Environmental Management, Springer Verlag New York, Volume32, no.1, pp, 116-127.

[20] Woodward. (2004) Is Municipal Solid Waste Recycling Economically Efficient, Journal of Environmental Management, Springer New York, Vol, 40, No.6, pp, 926-943.

[21] Khalid, 1993

[22] Feher, M. (2007) Measuring The Environmental Impact of Waste Flow Management in Braziliian Apartment building, Journal of Environmental Development and Sustainability, Springer, Netherlands

[23] Tchobanoglous, G. Theisen, H., and Vigil, S.A. (1993) Integrated Solid Waste Management Engineering Principles and Management Issues, International Edition, McGraw Hill publications, New York, pp, 27-34.

[24] World Bank, (1999) What A Waste; Solid Waste + Management in Asia, Washing DC, USA. 